\title{
Preparation and Biological Evaluation of Iodopromazine as a Radiopharmaceutical Model for Brain Imaging
}

M.A.Motaleb ${ }^{1}$, A.M.Othman ${ }^{2}$, I.T.Ibrahim ${ }^{1}$ and M.E.Moustafa ${ }^{3}$

${ }^{1}$ Hot Lab.Center, Atomic Energy Authority,Cairo, Egypt

${ }^{2}$ Egypt Second Research Reactor, Atomic Energy Authority,Cairo,Egypt

${ }^{3}$ Chem Dept.,Faculty of Sciences, Benha Univ., Benha, Egypt

E-Mail: abdullah_m_u@hotmail.com

\begin{abstract}
This study aimed to prepare a novel radiopharmaceutical for the detection of brain disorders at early stages in susceptible patients. Promazine hydrochloride was labeled with ${ }^{125} \mathrm{I}$ by direct electrophilic substitution reaction with high labeling yields of $92.6 \pm 3.24 \%$. The labeling yield and in vitro stability of ${ }^{125} \mathrm{I}$-promazine were determined by paper electrophoresis, paper chromatography (PC) and High performance liquid chromatography (HPLC). In vitro studies showed that the highest radiochemical yield of ${ }^{125}$ I-promazine $(92.6 \pm 3.24 \%)$ was stable up to $6 \mathrm{~h}$. Biodistribution studies showed that maximum uptakes of ${ }^{125} \mathrm{I}$-promazine in the brain of mice was $5.4 \pm 0.18 \%$ injected dose/g after 30 min post-injection which is higher than that of ${ }^{99 \mathrm{~m}} \mathrm{Tc}-\mathrm{HMPAO}$ and ${ }^{99 \mathrm{~m}} \mathrm{Tc}-\mathrm{ECD}$ (2.25 and $4.7 \%$, respectively), so this confirms the high specificity and selectivity of this radiotracer for brain and could be used for brain imaging instead of the commercially available ${ }^{99 \mathrm{~m}} \mathrm{Tc}-\mathrm{HMPAO}$ and ${ }^{99 \mathrm{~m}} \mathrm{Tc}-$ ECD.
\end{abstract}

Keywords: ${ }^{125}$ I-promazine hydrochloride (PMZ), Brain imaging, Electrophilic substitution, Radioiodination.

\section{Introduction}

Brain imaging technology is becoming an important tool in both research and clinical care. Due to the sensitivity of brain imaging technique, neuroscientists are able to visualize the structure and function of the brain from the level of individual molecules to the whole brain, recognize and diagnose neurological disorders, develop new strategies for treatment and determine how therapies work. The study aimed to development a potential candidate for non-invasive brain imaging exploiting the advantages of drugs which are able to cross the brain barrier. Single-photon emission computed tomography (SPECT) is the most commonly applied brain imaging technique in clinical practice which is used in regional cerebral blood flow (rCBF) measurement. The studying of human cognition was carried out by SPECT alone or SPECT combined with PET (positron emission tomography) and /or fMRI (functional magnetic resonance imaging). Imaging of neuro-receptor systems, aiding in diagnosis or assessment of progression of neurologic disorders and following the treatment response of psychiatric diseases. These techniques are also applied in neuropharmacologic challenge studies for molecular imaging of trans-gene expression [1-12]. The ideal isotope for imaging processes should have suitable short physical half-life and suitable gamma energy combatable with gamma camera. Technetium- $99 \mathrm{~m}$ and Iodine-123 are the most common isotopes that attain these characters whereas, selection any of them depend on the structure of the ligand to be labeled $[13,14]$. In the last decade the developing of functional brain imaging radiopharmaceuticals were rapidly progressed. Brain imaging in humans is currently achieved by using ${ }^{99 \mathrm{~m}}$ Tc-hexamethylpropyleneamine oxime ( $\left.{ }^{99 \mathrm{~m}} \mathrm{Tc}-\mathrm{HMPAO}\right)$ and ${ }^{99 \mathrm{~m}} \mathrm{Tc}$-ethyl cysteinate dimer $\left({ }^{99 m}\right.$ Tc-ECD) [15-17]. The major disadvantage of these compounds is their poor brain uptake in experimental animals $\left(2.25 \%\right.$ for ${ }^{99 \mathrm{~m}} \mathrm{Tc}-\mathrm{HMPAO}$ and $4.7 \%$ for ${ }^{99 \mathrm{~m}} \mathrm{Tc}$ ECD) and low stability [18-20].

Promazine hydrochloride (PMZ) is a phenothiazine drug which is consists of two phenyl rings connected by nitrogen and sulfur atoms, together with an aminopropyl chain and chemical designation is N,N-dimethyl-3- $(10 \mathrm{H}-$ phenothiazin-10-yl)-propan-1-amine, hydrochloride (Fig. 1). It is used for the treatment of schizophrenia and mania [21].

Postsynaptic dopamine receptors D1 and D2 in the medullary and mesolimbic chemoreceptor trigger zone (CTZ) were blocked by Promazine hydrochloride. Also, it blocks alpha-adrenergic receptors and possess strong anticholinergic activity.

The present study is focused on developing radioiodinated promazine hydrochloride to be used as novel radiopharmaceuticals for efficient brain imaging. Influence of parameters affecting radioiodination efficiency such as the amount of chloramine-T (CAT), the amount of $\mathrm{PMZ}, \mathrm{pH}$ of the reaction medium and the reaction time were investigated to optimize the maximum percent radiochemical yield. The biodistribution of ${ }^{125} \mathrm{I}-$ promazine has also been studied in albino mice.

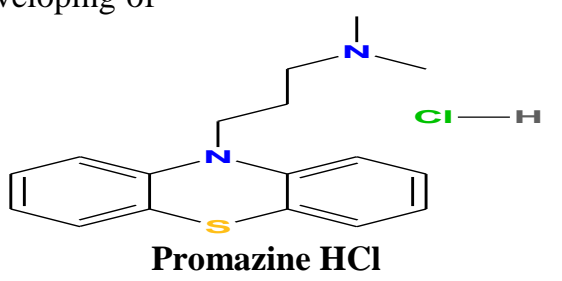

Fig (1) Chemical structure of promazine $\mathrm{HCl}(\mathrm{PMZ})$. 


\section{Materials}

Promazine $\mathrm{HCl}$ was obtained from Sigma, USA. The ${ }^{125}$ I was purchased from Isotopes Institute Co., Ltd. (IZOTOP), Budapest, Hungary. A NaI(Tl) gamma-ray scintillation counter (Scaler Ratemeter SR7 model, England) was used for measurement of gamma-ray radioactivity. All the chemicals used were of analytical grade. Albino mice, each of 20-25 g, were used for biodistribution studies.

\section{Methodology}

\subsection{Radioiodination of promazine}

Radiolabeled compound was synthesized by direct electrophilic substitution with ${ }^{125} \mathrm{I}$ under oxidative conditions in the presence of chloramine-T (CAT). Halflife $\left(t_{1 / 2}\right)$ of ${ }^{125}$ I was 59.4 days which suitable for practical experimental. The influence of various reaction parameters on radioiodination efficiency, such as the concentration of oxidizing agent (CAT), concentration of promazine, $\mathrm{pH}$ of the reaction, reaction time and reaction temperature, were investigated and optimized to maximize the radiochemical yield.

The reaction mixture volume was fixed to $500 \mu$ l. In an amber colored $10 \mathrm{ml}$ vial, $200 \mu \mathrm{l}$ of aqueous solution containing 10-500 $\mu \mathrm{g}$ of promazine was mixed with $140 \mu \mathrm{l}$ of freshly prepared CAT solution in water, containing 5$200 \mu \mathrm{g}$ of CAT. pH was adjusted by using $150 \mu \mathrm{l}$ of $1 \mathrm{M}$ phosphate buffer with different $\mathrm{pH}$ then, $10 \mu \mathrm{l}$ of ${ }^{125} \mathrm{I}(10$ $\mathrm{MBq}$ ) was added to the reaction mixture. The reaction mixture was shaken by vortex and left at room temperature. Radioiodination was stopped at specific reaction time using $10 \mu \mathrm{l}$ of high concentration of sodium metabisulfite solution $\left(10 \mathrm{mg} / \mathrm{ml} \quad \mathrm{H}_{2} \mathrm{O}\right)$ to quench radioiodination reaction [22].

\subsubsection{Analysis of ${ }^{125}$ I-promazine}

The labeling yield and in vitro stability of ${ }^{125} \mathrm{I}-$ promazine were determined by paper electrophoresis, paper chromatography (PC) and high performance liquid chromatography (HPLC).

\subsubsection{Electrophoresis}

Radiochemical yield was detected by paper electrophoresis using Whatman paper $(3 \mathrm{~cm}$ width and 50 $\mathrm{cm}$ length) where $10 \mu \mathrm{L}$ of the reaction mixture was placed at $15 \mathrm{~cm}$ away from the cathode. The process is carried out for $1 \mathrm{~h}$ at 300 volts using physiological saline $(0.9 \% \mathrm{w} / \mathrm{v}$ $\mathrm{NaCl}$ solution) as electrolytes source solution [23]. After complete development, the paper was dried and segmented into $1 \mathrm{~cm}$ strips then each strip was counted using the $\mathrm{NaI}(\mathrm{Tl}) \quad \gamma$-ray scintillation counter. The percentage of radiochemical yield was calculated according to the following equation:

$$
\% \text { Radioactivity }=\frac{\text { Fraction of }{ }^{125} \mathrm{I} \text {-promazine }}{\text { Total radioactivity }} \times 100
$$

\subsubsection{Paper chromatography (PC)}

Ascending paper chromatographic method was used to determine the radiochemical yields and in-vitro stability using strips of Whatman paper number 1. On a paper strip (1.5 cm width and $15 \mathrm{~cm}$ length), $5 \mu$ l of the reaction mixture were spotted on line (origin) at distance of $3 \mathrm{~cm}$ from the bottom and allowed to evaporate. After developing the paper in fresh mixture of methylene chloride: acetyl acetate m.p $(2: 1, \mathrm{v} / \mathrm{v})$ in an ascending manner inside closed jar, it was removed, dried, and segmented into $1 \mathrm{~cm}$ pieces. These pieces were also counted to determine the free radioiodide ratio and radioiodinated compound [22].

\subsubsection{High performance liquid chromatography (HPLC)}

The radiochemical purity of ${ }^{125} \mathrm{I}$-promazine was determined using HPLC. The reaction mixture $(30 \mu \mathrm{l})$ was injected into the column $(\mathrm{Rp}-\mathrm{C} 18,4 \times 250 \mathrm{~mm}, 5 \mu \mathrm{m}$, Lichrosorb) and UV spectrophotometer detector (SPD-6A) operated at $254 \mathrm{~nm}$. The elution process was carried out using Methanol : methylene chloride $(50: 50 \mathrm{v} / \mathrm{v})$ as mobile phases at a flow rate of $1 \mathrm{~mL} / \mathrm{min}$. Fractions of $0.5 \mathrm{ml}$ were collected separately using a fraction collector up to $10 \mathrm{ml}$ and counted in a well-type $\mathrm{NaI}(\mathrm{Tl})$ ) gamma-ray scintillation counter.

\subsection{In-vitro stability study}

The radiochemical yields of ${ }^{125}$ I-promazine was calculated to study in-vitro stability at different time post iodination. The reaction mixture was prepared at optimum condition and left at room temperature for 12 hours then 5 $\mu \mathrm{l}$ of sample was taken from mixture at different time intervals up to 12 hours. The radiochemical yields of the sample was measured by paper chromatography.

\subsection{Determination of the partition coefficient}

Partition coefficient experiment was carried out for in vitro evaluating of the ability of radiopharmaceuticals to pass through the brain barriers. Exactly $50 \mu \mathrm{L}$ of ${ }^{125} \mathrm{I}-$ promozine was mixed with equal volumes of octanol and water. The mixture was vortexed well at room temperature for $1.5 \mathrm{~min}$ and then centrifuged at $6,000 \mathrm{rpm}$ for $4 \mathrm{~min}$. Samples $(100 \mu \mathrm{L})$ from the formed two phases were putted into test tubes and counted using a gamma counter. Measurement was performed three times and the partition coefficient value was calculated as $\log p$ according to this equation [24]:

$$
\text { Log } P \text { oct/wat }=\log \frac{[\text { Solute] octanol }}{\text { [Solute] deionized water }}
$$

\subsection{Biodistribution}

The biodistribution of ${ }^{125}$ I-promazine was evaluated by quantitative determination of organ distribution, Groups of three mice were used for each experiment. Radioiodinated promazine $(2 \mathrm{MBq} / 10 \mu \mathrm{l})$ was injected into each mouse via the tail vein. The mice were sacrificed at 15, 30, 60 and 120 min post-injection, respectively. Blood samples were collected at the time of decapitation. Samples of fresh muscles, bone and blood were collected in pre-weighed vials and counted. Muscles, bone and Blood were calculated as 40,10 and $7 \%$ of the total body weight, 
respectively [25]. Whole brains were removed. Organs and tissues were collected and weighed.

The radioactivity of radiopharmaceuticals in each sample as well as the background was counted by gammaray counter. The mean percentage injected dose/gram (\% $\mathrm{ID} / \mathrm{g} \pm \mathrm{SD}$ ) is calculated.

\section{Results and discussion \\ 4.1 Radiochemical yield and purity \\ 4.1.1 Electrophoresis}

Analysis of reaction mixture samples revealed two peaks Fig (2), one corresponding to the free iodide, which moved toward the anode to a distance of $14 \mathrm{~cm}$, and the other peak corresponding to ${ }^{125}$ I-promazine, which remained at the point of spotting.

\subsubsection{Paper chromatography (PC)}

The radiochemical yield of ${ }^{125}$ I-promazine was determined by paper chromatography using fresh mixture mobile phase, free radioiodide $\left(\mathrm{I}^{-}\right)$remained near the origin $\left(R_{f}=0-0.1\right)$, while the ${ }^{125}$ I-promazine moved with the solvent front $\left(R_{f}=0.8\right)$.

\subsubsection{High performance liquid chromatography (HPLC)}

The radiochemical Purity of ${ }^{125}$ I-promazine was confirmed by HPLC analysis. HPLC radiochromatogram was shown in Fig. 3 showed two peaks, the first peak at retention time $4.3 \mathrm{~min}$, which corresponds to free radioiodide $\left(\mathrm{I}^{-}\right)$, while the second peak was collected at retention time $7.4 \mathrm{~min}$ for ${ }^{125} \mathrm{I}$-promazine which was found to coincide with its UV signal of promazine at retention time $7.2 \mathrm{~min}$.

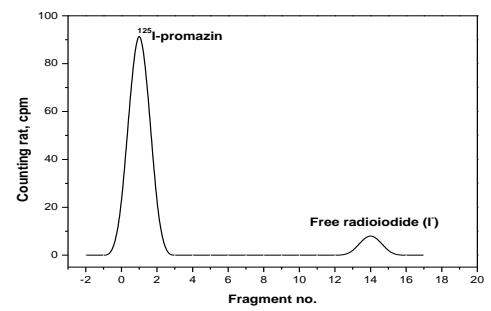

Fig (2) Electrophoretic pattern of ${ }^{125}$ I-promazine. Reaction conditions: $200 \mu \mathrm{g}$ of promazine $\mathrm{HCl}, 150 \mu \mathrm{l}$ phosphate buffer $(1 \mathrm{M})$ of $\mathrm{pH} 7,10 \mu \mathrm{l}$ of no carrier added $\mathrm{Na}^{125} \mathrm{I}(10 \mathrm{MBq}), 50 \mu \mathrm{g}$ of CAT in fixed volume of reaction mixture $(500 \mu \mathrm{l})$, kept at room temperature for $15 \mathrm{~min}$, Whatman paper sheet, 300 $\mathrm{V}$, and 1 hour.



Fig (3) HPLC radiochromatogram of ${ }^{125}$ I-promazine.

\subsection{Factors affecting the labeling yield 4.2.1 Effect of promazine amount}

The \% radiochemical yield of 125I-promazine was found to be dependent on the substrate's amount as shown in Fig (4). The reaction was performed at amounts of substrate ranged between 10 and $500 \mu \mathrm{g} / 500 \mu \mathrm{l}$ for promazine. The $\%$ radiochemical yield of $125 \mathrm{I}$-promazine was low at $10 \mu \mathrm{g} / 500 \mu \mathrm{l}(55.1 \pm 1.92 \%)$ and increased to reach optimum labeling yield at $200 \mu \mathrm{g} / 500 \mu \mathrm{l}(92.6 \pm 3.24$ $\%)$. Increasing promazine's amount above $200 \mu \mathrm{g} / 500 \mu \mathrm{l}$ led to slightly decrease in the labeling yield reaching 91.7 $\pm 3.20 \%$ at $500 \mu \mathrm{g} / 500 \mu \mathrm{l}$. These results can be explained by increasing the interaction between molecules of promazine and radioiodine till certain extent after which equilibrium was obtained [26, 27]. Thus, $200 \mu \mathrm{g} / 500 \mu \mathrm{l}$ of promazine was the optimum amount of substrate required to obtain maximum labeling yield.



Fig (4) Radiochemical yield of ${ }^{125} \mathrm{I}$-promazine as a function of promazine $\mathrm{HCl}$ amount. Reaction conditions: $\mathrm{x} \mu \mathrm{g}$ of promazine $\mathrm{Hcl}, 150 \mu \mathrm{l}$ phosphate buffer $(1 \mathrm{M})$ of $\mathrm{pH} 7,10 \mu \mathrm{l}$ of no carrier added $\mathrm{Na}^{125} \mathrm{I}(10 \mathrm{MBq}), 50 \mu \mathrm{g}$ of CAT in fixed volume of reaction mixture $(500 \mu \mathrm{l})$ and kept at room temperature for $15 \mathrm{~min}$.

\subsubsection{Effect of chloramine-T concentration}

Fig (5) showed the effect of CAT concentration on the percent radiochemical yield of 125I-promazine.

Radioiodination of promazine has been performed by using CAT as a mild oxidizing agent, transforming iodide (I-) to an electropositive form of iodine (oxidative state I+), which allows a spontaneous electrophilic substitution with $\mathrm{H}+$ [28]. When high specific activity of radioiodide is oxidized in-situ, it generates electropositive iodine. It is unlikely to form $\mathrm{I} 2$ because there is so little radioiodine present that is statistically not possible for two iodine atoms to join together at the concentrations involved [28]. CAT (although it is a mild oxidizing agent) is strong enough to oxidize all I- into I+ without forming I2.

At low CAT concentrations $(5 \mu \mathrm{g} / 500 \mu \mathrm{l})$ the radiochemical yield of 125I-promazine was small and equal to $42.7 \pm 1.49 \%$. This low yield may be due to the fact that the CAT concentration was not enough to reproduce the oxidative state of iodine (I+) [29]. The maximum radiochemical yield of 125I-promazine $(92.6 \pm 3.24 \%)$ was achieved by increasing the CAT concentration to $50 \mu \mathrm{g} / 500 \mu \mathrm{l}$.

Increasing the CAT concentrations above these values led to iodination decrease yield, which may be due to the undesirable oxidative by-products formation like chlorination, polymerization and denaturation of promazine $\mathrm{HCl}$ [30]. The formation of these impurities 
may be due to the high concentration and reactivity of CAT [30]. So, the optimum concentration of CAT was highly recommended to avoid the formation of any byproducts and to obtain the highest radiochemical yields [30].



Fig (5) Radiochemical yield of ${ }^{125}$ I-promazine as a function of using different concentration of CAT. Reaction conditions: $200 \mu \mathrm{g}$ of promazine $\mathrm{HCl}$, $150 \mu \mathrm{l}$ phosphate buffer $(1 \mathrm{M})$ of $\mathrm{pH} 7,10 \mu \mathrm{l}$ of no carrier added $\mathrm{Na}^{125} \mathrm{I}(10 \mathrm{MBq}), \mathrm{x} \mu \mathrm{g}$ of CAT in fixed volume of reaction mixture $(500 \mu \mathrm{l})$ and kept at room temperature for $15 \mathrm{~min}$.

\subsubsection{Effect of $\mathrm{pH}$ of the reaction medium}

The influence of the reaction mixture $\mathrm{pH}$ of on the radiochemical yield of ${ }^{125} \mathrm{I}$-promazine at different $\mathrm{pH}$ range (3-11) are shown in Fig. 6. The change in $\mathrm{pH}$ of reaction mixture may cause hydrolysis of radioiodinated compounds and may affect the efficiency of the oxidizing agent [30-32]. The radiochemical yield for each $\mathrm{pH}$ value of the reaction medium was measured and the $\mathrm{pH}$ value at which maximum radiochemical yield was obtained considered the optimum $\mathrm{pH}$.

At $\mathrm{pH} 3$, the radiochemical yield was $72.4 \pm 2.53 \%$ for ${ }^{125} \mathrm{I}$-promazine. The radiochemical yield decreasing was due to decreasing the efficiency of oxidizing agent at low $\mathrm{pH}$ [33].

At $\mathrm{pH} \mathrm{7,} \mathrm{the} \mathrm{maximum} \mathrm{radiochemical} \mathrm{yield}(92.6 \pm$ $3.24 \%$ ) of ${ }^{125}$ I-promazine was higher than other radiochemical yields.

By increasing the $\mathrm{pH}$ towards alkaline side, the radiochemical yield decrease to $62.4 \pm 2.18 \%$ at $\mathrm{pH} 11$ for ${ }^{125}$ I-promazine. The decrease in radiochemical yield at alkaline $\mathrm{pH}$ may be due to the formation of hypoiodite ion $\left(\mathrm{IO}^{-}\right)$and iodate $\left(\mathrm{IO}_{3}^{-}\right)$[34], which are not the suitable forms for radioiodination [35].

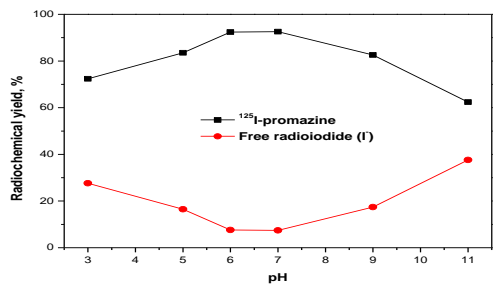

Fig (6) Radiochemical yield of ${ }^{125}$ I-promazine as a function of $\mathrm{pH}$. Reaction conditions: $200 \mu \mathrm{g}$ of promazine $\mathrm{HCl}, 150 \mu \mathrm{l}$ phosphate buffer $(1 \mathrm{M})$ of different $\mathrm{pH} 3-11,10 \mu \mathrm{l}$ of no carrier added $\mathrm{Na}^{125} \mathrm{I}(10 \mathrm{MBq}), 50 \mu \mathrm{g}$ of CAT in fixed volume of reaction mixture $(500 \mu \mathrm{l})$ and kept at room temperature for $15 \mathrm{~min}$.

\subsubsection{Effect of reaction time}

The radiochemical yield of ${ }^{125} \mathrm{I}$-promazine was studied at different reaction times (1-60 min). As shown in Fig. 7 that the radiochemical yields of ${ }^{125}$ I-promazine was increased with increasing the reaction time from 1 to 15 min. At shorter reaction time $(1 \mathrm{~min})$, the radiochemical yield was low because the time is not sufficient for reaction between chloramine-T and iodide to start the radioiodination. A reaction time of $15 \mathrm{~min}$ was needed to reach the maximum radiochemical yields of $(92.6 \pm 3.24$ $\%$ ) for ${ }^{125}$ I-promazine which was higher than other radiochemical yields at different reaction times. Increasing the reaction time more than the optimum values caused radiochemical yield decreasing due to exposing the substrate to highly reactive CAT for long reaction time which could result in oxidative side reactions.

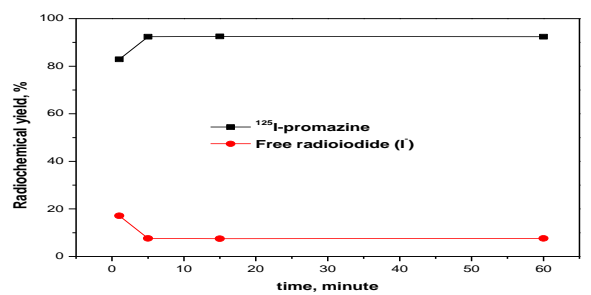

Fig (7) Radiochemical yield of ${ }^{125}$ I-promazine as a function of reaction time. Reaction conditions: $200 \mu \mathrm{g}$ of promazine $\mathrm{Hcl}, 150 \mu \mathrm{l}$ phosphate buffer $(1 \mathrm{M})$ of $\mathrm{pH} 7,10 \mu \mathrm{l}$ of no carrier added $\mathrm{Na}^{125} \mathrm{I}(10 \mathrm{MBq}), 50 \mu \mathrm{g}$ of CAT in fixed volume of reaction mixture $(500 \mu \mathrm{l})$ and kept at room temperature for different time.

\subsection{In-vitro stability study}

The effect of time post iodination on the in-vitro stability of ${ }^{125}$ I-promazine was studied to determine the suitable time post iodination during which the preparation remain having high radiochemical yields. Table 1 showed in-vitro stability at different time post iodination. In-vitro stability tests were carried out at different time post iodination which varied from 1 to 12 hours and the radiochemical yields were calculated. The highest radiochemical yield of ${ }^{125}$ I-promazine was stable up to $6 \mathrm{~h}$.

Table (1) In-vitro stability of ${ }^{125}$ I-promazine.

\begin{tabular}{lcccc}
\hline & \multicolumn{4}{c}{$\begin{array}{c}\text { Radiochemical yield (\%) } \\
\text { Time post iodination (h) }\end{array}$} \\
\hline & $\mathbf{1}$ & $\mathbf{4}$ & $\mathbf{6}$ & $\mathbf{2}$ \\
\hline $\begin{array}{l}\text { Promazine } \\
\text { HCl }\end{array}$ & 92.4 & 92.3 & 91.5 & 85.7 \\
\hline
\end{tabular}

\subsubsection{Partition coefficient study}

The partition coefficient values of ${ }^{125}$ I-promazine $\mathrm{Hcl}$ was $1.931 \pm 0.03$, showing that the iodocompounds are lipophilic and can cross the blood-brain barrier [36].

\subsubsection{Biodistribution}

Biodistribution patterns of labeled drugs in normal mice were presented in Table 2. The high uptake of radioactivity in liver indicates that the metabolism of 
radioiodinated promazine occurs mainly through liver [37]. The accumulation of the iodocompounds in lungs is attributed to that lungs may function as a reservoir for antidepressants with high affinity to the serotonin transporter [38]. The results showed that the highest brain uptake was $5.4 \pm 0.18 \% \mathrm{ID} / \mathrm{g}$ organ at $30 \mathrm{~min}$ postinjection which slightly decreased to $4.99 \pm 0.17 \% \mathrm{ID} / \mathrm{g}$ after 60 min post-injection, then decreased to $3.7 \pm 0.12 \%$ $\mathrm{ID} / \mathrm{g}$ after $2 \mathrm{~h}$ for radioiodinated promazine. These values of radioiodinated promazine brain uptake was higher than that of currently used radiopharmaceutical for brain imaging whereas the ${ }^{99 \mathrm{~m}} \mathrm{Tc}-\mathrm{HMPAO}$ has maximum brain uptake of $2.25 \% \mathrm{ID} / \mathrm{g}[39,40]$ The result also showed that $10-30 \mathrm{~min}$ is the optimum time to be used as brain imaging agents. Also, radioiodinated promazine is stable up to 6 , while ${ }^{99 \mathrm{~m}} \mathrm{Tc}-\mathrm{HMPAO}$ is stable up to $30 \mathrm{~min}$. This indicates that radioiodinated promazine may be better agents for brain SPECT than ${ }^{99 \mathrm{~m}}$ Tc-HMPAO.

Table (2) Biodistribution of ${ }^{125}$ I-promazine in normal mice.

\begin{tabular}{lcccc}
\hline Organ \& body fluid & \multicolumn{4}{c}{$\begin{array}{c}\text { \% ID/gram organ } \\
\text { Time post-injection (min) }\end{array}$} \\
\cline { 2 - 5 } & $\mathbf{1 5}$ min & $\mathbf{3 0}$ min & $\mathbf{6 0}$ min & $\mathbf{1 2 0}$ min \\
\hline Brain & $3.5 \pm 0.12$ & $5.4 \pm 0.18$ & $4.99 \pm 0.17$ & $3.7 \pm 0.12$ \\
Muscle & $2.1 \pm 0.07$ & $2.4 \pm 0.08$ & $2.8 \pm 0.09$ & $2.7 \pm 0.09$ \\
Blood & $15.7 \pm 0.54$ & $12.3 \pm 0.43$ & $7.9 \pm 0.27$ & $5.4 \pm 0.18$ \\
Thyroid & $1.2 \pm 0.04$ & $1.9 \pm 0.06$ & $2.3 \pm 0.08$ & $4.5 \pm 0.15$ \\
Liver & $10.7 \pm 0.37$ & $15.2 \pm 0.53$ & $11.2 \pm 0.39$ & $9.8 \pm 0.34$ \\
Spleen & $1.1 \pm 0.03$ & $1.3 \pm 0.04$ & $1.5 \pm 0.05$ & $1.2 \pm 0.04$ \\
Intestine & $2.1 \pm 0.07$ & $3.9 \pm 0.13$ & $6.4 \pm 0.22$ & $4.3 \pm 0.15$ \\
Stomach & $3.2 \pm 0.11$ & $4.6 \pm 0.16$ & $6.7 \pm 0.23$ & $6.3 \pm 0.22$ \\
Lungs & $4.5 \pm 0.15$ & $4.6 \pm 0.14$ & $3.9 \pm 0.13$ & $3.1 \pm 0.10$ \\
Heart & $6.9 \pm 0.24$ & $6.2 \pm 0.21$ & $5.4 \pm 0.18$ & $4.2 \pm 0.14$ \\
Bone & $1.2 \pm 0.04$ & $1.7 \pm 0.05$ & $1.9 \pm 0.06$ & $2.2 \pm 0.07$ \\
\hline
\end{tabular}

Values represent mean $\pm \operatorname{SD} n=3$

\section{Conclusion}

In this study, promazine was labeled with ${ }^{125} \mathrm{I}$ by direct electrophilic substitution reaction with high labeling yields of $92.6 \pm 3.24 \%$, using CAT as oxidizing agent. This study showed good in vitro and in vivo stability of radioiodinated promazine. Radioiodinated promazine is more stable than the commercially available ${ }^{99 m}$ Tc-ECD and ${ }^{99 \mathrm{~m}} \mathrm{Tc}-\mathrm{HMPAO}$. The brain uptake of radioiodinated promazine $\mathrm{HCl}$ was $5.4 \pm 0.18 \%$ injected dose/g at $30 \mathrm{~min}$ post-injection, which is higher than that of ${ }^{99 \mathrm{~m}} \mathrm{Tc}-\mathrm{HMPAO}$ and ${ }^{99 \mathrm{~m}} \mathrm{Tc}-\mathrm{ECD}(2.25$ and $4.7 \%$, respectively). So, radioiodinated promazine may be used as radiopharmaceutical model for brain imaging and better than the commercially available agents for that purpose. Further clinical investigation is needed for application of radioiodinated promazine as brain imaging agent.

\section{References}

[1] M.D. Sr. Devous. Eur J Nucl Med Mol Imaging, Vol.29, PP.1685-1696, 2002.

[2] A.M. Catafau. J Nucl Med, Vol.42, PP.259-271, 2001.

[3] A.W. Toga, J.C. Mazziotta. Brain mapping: the methods, 2nd edn. Academic Press, San Diego, PP. 513-533, 2002.

[4] B. Lee, A. Newberg. NeuroRx, Vol.2, PP.372-383, 2005.

[5] F.J. Bonte, M.D. Devous. In: Sandler MP, Coleman RE, Patton JA, Wackers FJTh, Gottschalk A (eds) Diagnostic nuclear medicine, 4th edn. Lippincott
Williams and Wilkins, Philadelphia, PP. 757-782, 2003.

[6] Sr. Devous MD. In: Murray IPC, Ell PJ (eds) Nuclear medicine in clinical diagnosis and treatment, 2nd edn. McGraw-Hill, New York, PP. 631-649, 1998.

[7] D.J. Brooks. NeuroRx, Vol.2, PP.226-236, 2005.

[8] T. Eckert, D. Eidelberg. NeuroRx, Vol.2, PP.361371, 2005.

[9] A. Heinz, D.W. Jones, T. Raedler, R. Coppola, M.B. Knable, D.R. Weinberger. Nucl Med Biol, Vol.27, PP.677-682, 2000.

[10] B.C. Dickerson, R.A. Sperling. NeuroRx, Vol.2, PP.348-360, 2005.

[11] R. Bammer, S. Skare, R. Newbould, C. Liu, V. Thijs, S. Ropele, D.B. Clayton, G. Krueger, M.E. Moseley, G.H. Glover. NeuroRx, Vol.2, PP.167196, 2005.

[12] R.I. Kuzniecky. NeuroRx, Vol.2, PP.384-393, 2005.

[13] M. El-Tawoosy, N. Farouk, A.S. El-Bayoumy. J Radioanal Nucl Chem, Vol.290, PP.595-600, 2011.

[14] N. Farouk, M. El-Tawoosy, S. Ayoub, A.S. ElBayoumy. J Radioanal Nucl Chem, Vol. 290, PP.685-690, 2011.

[15] Ogasawara K, Ogawa A, Ezura M, Konno H, Suzuki M, Yoshimoto T. Am J Neuroradiol, Vol.22, PP.48-53, 2001.

[16] C. Chang, Y. Shiau, J. Wang, S. Ho, A. Kao. Ann Rheum Dis 61:774-778, 2002. 
[17] F.J. Bonte, L. Hynan, T.S. Harris, C.L. White. Int J Mol Imaging 2011(ID 409101), PP.3, 2011.

[18] R.C. Walovitch, T.C. Hill, S.T. Garrity, E.H. Cheesman, B.A. Burgess, D.H. O’Leary, A.D. Watson, M.V. Ganey, R.A. Morgan, S.J. Williams. J Nucl Med, Vol.30(11), PP.1892-1901, 1989.

[19] R.D. Neirinckx, L.R. Canning, I.M. Piper, D.P. Nowotnik, R.D. Pickett, R.A. Holmes, W.A. Volkert, A.M. Forster, P.S. Weisner, J.A. Marriott, S.B. Chaplin. J Nucl Med, Vol.28, PP.191-202, 1987.

[20] M. A. Motaleb, I. T. Ibrahem, V. R. Ayoub and A. S. Geneidi. J. Lable Compd. Radiopharm, Vol.59,PP. 147-152, 2016.

[21] M.A.Rub, D.Kumar, N. Azum, et al. J Solution Chem 43: 930. doi:10.1007/s10953-014-0174-3 and Attwood, D., Florence, A.T.: Surfactant Systems, Their Chemistry, Pharmacy and Biology. Chapman, 2014.

[22] M. A.Motaleb, M. T.El-Kolaly, H. M. Rashed, A.Abd El-Bary. J. Radioanal. Nucl Chem, Vol.10,PP. 1499-1507, 2011.

[23] M.A. Motaleb, M.T. El-Kolaly. Rashed HM and Abd El-Bary A. J Radioanal Nucl Chem, Vol.292, PP. 629-635, 2012.

[24] F.E.I. Liu, H.E. Youfeng, Z. Luo. IAEA, Austria, Technical Reports Series No, Vol.426, PP. 37-52, 2004.

[25] B.A. Rhodes. Sem J Nucl Med, PP. 4:281, 1974.

[26] N.R.A. El-Mouhty, W.S. Shehab. Int J Basic Appl Sci, Vol.1(3), PP.260-269, 2012.

[27] M. El-Tawoosy, I.T. Ibrahim. Radiochemistry, Vol.54(4),401-406, 2012.
[28] M. J.Adam, D. S.Wilbur. Scott, Chem. Soc. Rev, Vol.34(2),PP. 153-163, 2005.

[29] K. M.El-Azony. J. Radioanal. Nucl. Chem.; 285, 315-320, 2010.

[30] Puttaswamy, Sukhdev, A., and Shubha, J. P. J. Mol. Cat. A: Chem, Vol.310,PP. 24-31, 2009.

[31] F. C.Green, W. M.Hunter, J. S.Glover, J. Biochem, Vol.89,PP. 114-123, 1963.

[32] Puttaswamy, N.Vaz. Trans. Met. Chem, Vol.28,PP. 409-417, 2003.

[33] Ramalingaiah, R. V.Jagadeesh, Puttaswamy. J. Mol. Cat. A: Chem, Vol.265(1),PP. 70-79, 2007.

[34] R.Haque, S. A.Ahmed, A. Fisher, C. C.Avila, J.Shi, A.Guo, T.Craig Cheetham, J. E.Schottinger. Cancer Med, Vol.1(3),PP. 318-327, 2012.

[35] M. A.Motaleb, M. E. Moustapha, I. T.Ibrahim. J. Radioanal. Nucl Chem.; DOI 10.1007/s10967-0111069-z, 2011.

[36] N. Roland, S. Fritz, E. Helmut, Clin. Microbiol. Rev, Vol.23(4),PP. 858-883, 2010.

[37] J. Fang, M. Bourin, G.B. Baker. Naunyn Schmiedebergs Arch Pharmacol, Vol.359(2), PP. 147-151, 1999.

[38] T. Suhara, Y. Sudo, K. Yoshida, Y. Okubo, H. Fukuda, T. Obata, K. Yoshikawa, K. Suzuki, Y. Sasaki. Lancet, Vol.351, PP.332-335, 1998.

[39] M.K. Rainer. Neuropsychiatr Dis Treat, Vol.4(5), PP.919-927, 2008.

[40] S.M. Stahl. Essential psychopharmacology, 2nd edn. Cambridge University Press, Cambridge, PP. 425-434, 2000. 